\title{
The unhallowed art: Literature and literary fakes in Australia
}

The fiction of Peter Carey is peopled by the unhallowed; by ghosts and the ghostly. In Bliss (1981), Carey presents us with the Dantesque trials of an advertising executive after he has a heart attack on his front lawn. In The Unusual Life of Tristan Smith (1994), phantom nations are inhabited by simulacra. In True History of the Kelly Gang (2001), a dead bushranger talks. Carey's My Life as a Fake (2003), the subject of this essay, gives us an apotheosis of this literary habit of bringing the unliving to life. It presents us with the flesh-and-blood, machete-wielding, gladiatorial figure of Bob McCorkle, a poet created as a literary hoax.

Ghosts can terrify. Take Stanley Kubrick's The Shining, in which twin girls, murdered by their father, hold hands in the lurid corridors of the hotel, or The Exorcist, in which a ghost plays at being a ventriloquist with the body of a teenage girl. Indeed, ghosts often want to talk. They return from the dead not only to shock but also to tell things to the living - notably, in the cause of justice. They corrupt reality in order to correct it. In Hamlet and Macbeth, for example, Kings return from beyond their graves, armour-clad or bloody, to expose frauds and murderers.

Certainly, Carey's ghosts tend to come with a dual agenda that involves not just unsettling us but also expanding our understanding of what is real - in the interests of what is right. Carey's ghosts are also peculiarly concerned with Australian crimes: both crimes committed against Australia and crimes committed by Australians. With Jack Maggs (1997), for example, Charles Dickens' Australian convict Magwitch returns from the literary grave to challenge his inferior status as a colonial outcast. Illywhacker (1985), on the other hand, reminds Australia of its own sins. The novel presents us with a grotesque trickster, the 'bullshit artist' of Australian lore, who takes on various forms and who finds himself troubled by misshapen visions of Chinese massacres on the gold fields.

My Life as a Fake is the story of a literary fraud perpetrated by a struggling Australian poet named Christopher Chubb. It is a story about a disembodied poet, construed as recently deceased and working-class and given the name of Robert McCorkle, who becomes embodied at the age of 24. McCorkle materializes in court, when his duped publisher, David Weiss, is tried on obscenity charges as a result of sexual innuendo in the faked poems. McCorkle is a massive, black-haired and angry spectre, pieced together by Chubb, Frankenstein-like, from photographs of three men including an Australian Rules footballer. At his publisher's trial, McCorkle calls the prosecutor a 'fucking philistine' (2003, p. 58) and shrugs off the court attendants. He hunts down and scalps the police officer in charge of the 
prosecution. He also pursues his publisher to lend him his support, but Weiss falls out of his apartment window from fear and dies. McCorkle then turns resentfully towards Chubb, proverbially rattling the ball and chain, mercilessly tormenting him, even going so far as to abduct Chubb's adopted daughter. When Chubb tracks McCorkle and his kidnapped daughter to Malaysia, McCorkle looms like Marlon Brando playing Kurtz in Apocalypse Now. His head, now shaved, is 'hard and shiny...like bone' (p. 219). Chubb reflects, 'if he was a figment of my imagination he was a nastier thought than any I'd ever had.'

This ghoul, like Frankenstein's monster, is angry - not just at his creator, Chubb, but at Australia, both of which he has spurned because they have both spurned him. He pursues his literary vocation in Malaysian jungles wracked by warfare, cruelty and disease. His poetry, inscribed on paper made from wild orchids and tree bark, is coveted by Sarah Wode-Douglass, the struggling editor of an English poetry journal, The Modern Review, as that of a genius.

McCorkle is, as ghosts can be, sublime (think of God's manifestation to Moses in the form of the burning bush or of the mesmerising lights of The Poltergeist): McCorkle is both terrible and beautiful. That terror and beauty, as is often the case when it comes to not only traditions of otherworldly creatures but also of that otherworldly phenomenon of aesthetic experience, are associated with truth. Certainly, Carey's novel, based on the 1944 Ern Malley hoax and published in a post-1990s climate of multicultural literary frauds, gives us good reason to believe Carey's spectral poet is trying to tell us something about the real world - or at least the place of literature in it.

So what is Carey trying to uncover through the ominous form of this fictive poet, this figure dredged up from the sacred beyond, home of not only ghosts but of the aesthetic - of horror and truth? In this paper, I would like to read McCorkle as a phantom addressing what Carey sees as crimes committed against literature in the Australian public sphere.

The unhallowed figure of the unliving poet is certainly suggestive of not only the unhallowed status of living poets but of literature generally, which seems to have become increasingly unholy, at least for some sectors of contemporary Australian public culture. Those who seem to have experienced the fall of literature most intensely and who have articulated it most profoundly in the public sphere are among those whose livelihoods most depend on literature: literary academics and publishers. However, the fragile status of literature in contemporary Australian public culture is hardly the rhetorical invention of literary academics or disillusioned publishers. Exposures of literary fakes, such as the Ern Malley hoax, have provided historical occasions for a much more widespread dissatisfaction about the category of literature to be expressed. However, literary frauds are themselves an effect of the condition of literature in public culture - although they arguably also contribute a cause - and so I'll first examine the wounds in the status of literature itself.

Given that ghosts typically appear with an agenda that involves exposing murders and that McCorkle haunts Australian literature, in what ways could we say that Australian literature has been slain over the years?

Having posed that question, the book in Australia is by no means dead. In fact, the book continues to be a commodity of commercial value, and the quantity of books published and bought is unprecedented. However, quality is something that a number of academics and publishers believe has been 
sacrificed. Hilary McPhee, for example, laments that publishing houses are now 'not much more than marketing and sales machines. The old maxim rules: the reader is a mug and the writer is a commodity - sell 50,000 copies before anyone discovers they're not much good.' (2001, p. 1) In the celebrity culture that dominates the marketplace, the quality of the book has also allegedly been killed off in favour of the saleability of the author. Susan Lever, for example, describes the literary as something that has been 'sacrificed to the cult of the personality' (1993), and in the literary arena, the author's personality can certainly occupy a cultish status, positioned according to Romantic tradition as the privileged locus of truth.

Among readers of a category becoming increasingly known as the middle brow - an urban, economically privileged, middle-aged, leisured, festivalattending and feminised class of book buyers - the book itself is said to have become secondary to the watched and shared experience of going to the bookshop and reading the 'right' books. In the tradition of Pierre Bourdieu, who described literature as little more than a status symbol in a social game that revolves around accumulating and displaying cultural capital, David Carter similarly describes books and reading as 'lifestyle and identity "accessories"' (2001-2). Carter has argued that middle brow readers have a particular taste for 'books that deal (stylishly) with "issues"' or deep moral and political questions.' Literature, long associated with humanism, has been transformed, through the fetishizing processes of market capitalism, into an apotheosis of ethical value. Thus literature has allegedly been lost to a fetishized humanist function - and not just for a middle brow reading public. Judges of literary prizes and grants have been similarly accused of evaluating literature in this way, charges levelled most obstreperously in the light of literary hoaxes.

As for the role of the humanities in the universities, economic rationalism along with Bourdieu-style cultural materialism has seen literature become decreasingly valued as an object for academic study. While economic rationalism renders economically unproductive activities suspicious, cultural materialists dismiss the aesthetic experience as little more than a reactionary illusion and suggest that, as Peter Goodall writes in High Culture, Popular Culture: The Long Debate, 'the continued existence of English is like the class war carried on by other means.' (1995, p. 150) Has literature been poisoned by a contradictory cocktail of capitalist praxis and Marxist theory?

Elizabeth Beaumont Bissell asks in The Question of Literature: The Place of the Literary in Contemporary Theory, 'What other discipline so routinely diminishes and decries its own objects?' $(2002$, p. 3) The question is significant. Literary academics have come under scrutiny from non-academic literary critics for an approach to literature that neglects the aesthetic dimension in favour of the ideological and politicizes the idea of literary quality. (note 1) The academy, however, does not function in isolation from the public sphere, and undoubtedly these attempts to democratize (or do away with) literary studies have been formulated partly in response to public culture, which has long accused literary academics of reactionary aestheticism and ivory towerism. This form of cultural ressentiment - which isn't solely class based, for the rich and powerful are celebrated - is often perceived as peculiarly marked in Australia, attributed to an enduring colonial mentality and viewed as a kind of displaced hostility for the old colonial power. Significantly, Australian academics were and continue to be among the leaders of not only postcolonial studies - which challenged the special claims of the language and literature of the mother country - but also of cultural materialism. 
Literary fakes are arguably viewed as events that do the greatest damage to the status of literature in the public sphere. They have also provided opportunities for hostility towards so-called cultural gatekeepers to be expressed. As such, as I have suggested, literary fakes are also a manifestation of the 'damaged' condition of literature. They are designed to successfully infiltrate literary culture - and sometimes to blow it up - and as such they show a fine understanding of their target. If the 1990s, as Maggie Nolan and Carrie Dawson argue in their introduction to a special issue of Australian Literary Studies devoted to literary fakes, unleashed 'a flood of disclosures about hoaxes and impostures', this was a direct result of an environment in which 'the currency of literary value fluctuated wildly.' (2004, p. viii)

Thus we find that in a contemporary literary culture that privileges author identity and fetishized ethical value, literary hoaxers - from Helen Demidenko to Norma Khouri - have tended to express themselves through autobiographical or semi-autobiographical discourses and to adopt ethnic identities. Ethnic identities, as I have argued at length elsewhere (note 2), are viewed as privileged sites of authenticity (according to age-old primitivist discourses) as well as appropriate symbols for public displays of fashionable middle brow identification, satisfying what David Boyle (2003) describes as a renewed lust for authenticity and humanity - ironically figured as products for sale - in our increasingly technological age.

Leon Carmen, creator of the Aboriginal Wanda Koolmatrie persona and author of Koolmatrie's autobiography My Own Sweet Time (1994), provides a good example of a hoaxer savvy to the contemporary function of literature in public culture. He managed to defraud the indigenous publishing house Magabala Books, the judges of the 1995 Nita May Dobbie Award for a first novel by a woman, the committee choosing texts for the 1996 NSW high school English curriculum, and the judges of the 1996 NSW Premier's Prize for Literature who short-listed the book. Carmen, who cooked up the hoax with his literary agent John Bayley, explained his mind set: 'The time seemed to be ripe. Authors as personalities were attracting more attention than their books. And the publishing world seemed to be regulated by academics promoting their various hobby horses.' (qu. Nolan 2004, p. 135)

Maggie Nolan argues that 'What is at stake here...is a fantasy of white supremacy and white male entitlement to positions of cultural dominance...the purpose of the hoax was to prove that Carmen is, in fact, worse off than Wanda Koolmatrie.' (p. 146) This is, I think, an accurate synopsis of Carmen's ideology and motivation. However, the ghost of Koolmatrie nevertheless served to draw out some of the complex truths about literature's function in Australia today.

Literary frauds make front-page news in a public culture that otherwise increasingly marginalises literature (note 3), suggesting another disturbing truth about Australian public culture. As Nolan and Dawson point out, the instances of literary hoaxes are 'statistically insignificant, and yet many were front-page news.' (2004, xiii) What becomes interesting, then, is the peculiar interest that Australian audiences seem to take in literary fakes. The readiness of journalists and of the public to react violently to literary fraudulence suggests that a deep-seated and class-based suspicion about the category of literature - as well as of its readers, publishers and academics, whom Nolan and Dawson describe as the 'self-professed cultural elites' (xi) typically targeted by literary fakes - seems to exist among the Australian public. However, readers, publishers and academics themselves also express a considerable amount of anxiety about the authenticity of Australian literature 
in the wake of literary hoaxes - manifested in the attention they pay to it (note 4) - suggesting a morbid insecurity in regards to the validity of Australian culture. While Nolan and Dawson correctly point out that literary frauds happen in other countries as much as they do in Australia and argue that there is no 'distinctive or peculiar national pathology that underpins the practice' (vii), the special attention that Australians pay to literary fakes nevertheless suggests that there may be something going on. As Dawson later concedes, 'Australians have been shaped by, and...respond to, long-standing representations of themselves as secretive degenerates, mimicking the English at the edge of empire.' (2005, p. 12) The pressure of public doubt about literary pursuits may also be an issue.

Indeed, the exposure of literary fakes tends to lead to the reprisal of what are, as the Ern Malley hoax on which Carey's novel is based reminds us, longstanding arguments in the Australian public sphere about the authenticity of the literary. The Ern Malley affair, on which Carey's novel is based, mobilised class-based conflict about literature's public status. James McAuley and Harold Stewart may have constructed the working-class poet Ern Malley as an avant-garde 'in joke' directed, as Brian Lloyd puts it, 'against another avant-garde text' (2001, p. 31). However, as David Musgrave and Peter Kirkpatrick recognize, Malley was not only a 'performance within high culture' but was also 'inextricably bound up with popular culture' and 'socially produced by very different frictions issuing from below' (2000, p. 137). When McAuley and Stewart criticized what they perceived to be the 'arty-farty' (McAuley qu. Lloyd 2001, p. 23) meaninglessness of the modernist poetry favoured by Max Harris and his journal Angry Penguins (where the Malley poems appeared), they did so by constructing a figure who represented the average Australian.

They also revealed their hoax in a tabloid newspaper, thus engaging Australian working class ressentiment against the 'cultural elite' to support their case. According to Cassandra Atherton, 'the public was delighted by the hoax... The Bulletin...lent their support to the McAuley/Stewart cause at the time, publishing the comment: "earnest thanks to the diggers who are joint debunkers of Bosh, Blah and Blather"' (2002, p. 16). When Max Harris (like David Weiss in Carey's novel) was subsequently put on trial for publishing bscenities, literature itself, perceived as a foreign, undemocratic, decadent and un-Australian activity, was clearly the offender. As Philip Mead points out, 'That a State's heaviest legal ordinance could be mobilised....against a handful of poems and a few other passages of a literary magazine is surely evidence that something more than a merely literary dispute was being tried' (1995, p. 87).

Carey's My Life as a Fake takes the Malley hoax of 1949 as its starting point. The details of the Malley hoax are uncannily echoed in Carey's novel. Christopher Chubb, a poet - like McCauley and Stewart - is the hoaxer. The hoax is carried out in an identical way to the Malley fraud. Chubb invents a sister for McCorkle, who humbly sends the poems of her deceased brother, figured as a former insurance agent and mechanic - identically to Malley - to the literary magazine Personae. (Indeed, fragments of the letter penned by Malley's sister are used in the novel, along with excerpts of Malley's poems.) Chubb's agenda - similarly to McAuley's and Stewart's - is to expose the fake sensibilities of an editor of a literary magazine. Chubb claims to have been concerned by 'the decay of meaning' (2003, p. 63), believing Weiss would publish the poems, which Chubb had pieced together from various learned sources, not only because Weiss could not recognize poetic truth but also because of McCorkle's working-class status. Chubb explains: 'I knew young Weiss had lost his schnozzle. He would so want pearls in the shit of swine, so 
want the genius to be a mechanic that he would never stop to question the evidence.'

While Carey's novel is rooted in the past, it is also linked to the present. The story's narrator is a contemporary figure, Sarah Wode-Douglass, the editor of an English poetry journal, The Modern Review, which survives only due to the largesse of three benefactors. She is taken to Malaysia by an old English poet, John Slater, who had in his life, according to Wode-Douglass, 'whored and sucked up' more than he wrote (p. 7). There, she accidentally encounters Chubb, and he introduces her to McCorkle's poetry, telling her the story of how he 'brought forth' a poet 'from hell... I imagined someone and he came into being' (p. 98). Wode-Douglass listens to Chubb's story only for the chance to secure McCorkle's poetry, which she experiences as the work of a genius and the find of a life time. For her, 'This was worth being born for, this single giddy glimpse, on this high place, with the sound of my own blood singing in my ears.' (p. 241) However, while she asserts that 'for a civilised man great poetry is beyond diamonds' (p. 250), her investors prove more interested in civility than poetry. When she telephones one of her benefactors at an improper hour to implore him for money, she is cut. Wode-Douglass, however, continues in pursuit of the genius of McCorkle. Narrating the story, she tells us she has been following his mystery now for thirteen years. Poetry, despite its dire status in public culture, is presented as resoundingly worth it.

In fact, in the novel, literature is embraced more violently by the working class than by the wealthy. Mrs Lim, a battle-scarred Chinese woman who becomes McCorkle's partner, and Tina, Chubb's abducted daughter, construct a shrine to McCorkle in the aftermath of his death and defend his work with their life. Indeed, when Chubb ultimately attempts to steal a volume of McCorkle's poetry, they kill him. Tina describes their symbiotic relationship with both the poet and his poetry: 'Bob McCorkle is the tree-ah...we are the roots. These poems are the flowers' (p. 238) Carey, through the spectre of McCorkle, similarly negotiates the class conflicts surrounding literature in the Australian public sphere. While the novel is clearly critical of a philistine, masculinist, sporting Australian culture - which persecutes the 'aesthete' and 'alien' (p. 55) Weiss - it nevertheless represents Bob McCorkle as a stereotypically Australian, working class, male character. While in the 'fragile' (p. 17) cultural climate of Australia, as Slater suggests, literary fakes can have a significant impact, Carey strongly argues that Australian literature exists.

In fact, stressing the power of literature is Carey's agenda. At his 2003 appearance at the Melbourne Writers' Festival to promote My Life as a Fake, Carey encouraged readers to interpret the book not in terms of the Ern Malley hoax but in terms of the 'primitive, magical thinking' (Carey's terms) that drives literature, something he alleged journalists and academics alike neglect. Indeed, in Carey's novel, the ghostly figure of Bob McCorkle serves not only to remind us of the injuries committed against literature - less in the form of literary fakes than in the public culture that gives birth to them - but also to defend what Carey believes to be the sublime power of the literary experience. Ultimately, McCorkle is offered as a redemptive figure for Australian literature, someone akin to Christ, suffering 'for the sake...of art itself, and for a country where we seldom understand that we must be prepared to fight for issues bigger than an umpire's decision.' (p. 78)

While this sounds like the eminently saleable and old-fashioned romantic view of the author, Carey's appearance as a celebrity author at the literary festival is ironic given that one of the other things he seems to be trying to suggest through the ghostly McCorkle is that the author has been falsely crowned. McCorkle, the product of a hoax, is presented as emphatically 
physical, and his work is that of an authentic genius. On the other hand, Chubb, the perpetrator of the hoax, is presented as an irresponsible Frankenstein but also finally redundant.

Unlike Frankenstein's monster, McCorkle is never interested in earning the love of his creator. He wants to save his publisher, Weiss, who is presented as the true believer. Indeed, Chubb - not McCorkle - is presented as barely real. In Malaysia, where Wode-Douglass encounters him, Chubb is physically diminished. He is thin and ragged with sores covering his legs. Even his suit is so fragile that it cannot withstand dry-cleaning. Indeed, in Malaysia, Chubb is regarded with hostility as a hantu or a ghost. A tailor warns Wode-Douglass in broken English: 'He not a person.' (p. 121) When Wode-Douglass listens to Chubb tell the story of McCorkle, he appears to her as a medium, channelling his characters - Bob McCorkle and his sister - from the other side. Watching Chubb, she is 'reminded of a completely unnerving séance I once attended in Pimlico where an old Welsh woman suddenly began talking like a posh young man.' (p. 31) However, while the novel presents us with this Yeatsian vision of the artist at work, magically tapping into a universal flow of genius, Chubb is hardly a noble figure even in this context. Unlike the heroes who appear in Yeats' 'Long-Legged Fly' - Michelangelo, Helen of Troy - whose minds move upon the mysterious and silent stream of inspiration, Carey's novel gives us a vision of Chubb sailing wildly down a literal stream, strapped by hostile Malaysians to a wicker float designed to disintegrate (parodically reminiscent of The Mission).

McCorkle, on the other hand, is nearly seven feet tall with a 'great forehead like the bust of Shakespeare' (p. 51) and legs like 'hairy fence post[s]' (p. 219). He fixes cars and wrestles with machete-wielding bandits in the primeval mud of the Malaysian jungle. Indeed, the brute physicality of this non-existent poet is one of his most defining features. Even the work he produces is insistently physical. His books, made from organic matter - tree bark and fibre, leaves and flowers - are skin-like in their texture, being 'slightly oily in places, scaly in others.' (p. 232). They are exotically material. In addition, the work is produced in an environment that is brutishly real, wracked as it is by colonial aggression - by the Japanese and Chinese as well as Westerners - and the Malaysian fight for independence. McCorkle, along with his assistants, Tina and Mrs Lim, fight hard to procure the materials for McCorkle's books. The genius of McCorkle's work, as Wode-Douglass describes it, also lies in its violent materiality: 'He had ripped up history and nailed it back together with its viscera on the outside, all that glistening green truth showing in the rip marks.' (p. 241)

When the dying McCorkle, lying in the arms of Chubb like his 'own vital organs' (p. 262), hands over his manuscript, entitled My Life as a Fake, the moment is distinctly schizophrenic. McCorkle says: 'I labour all my bloody life to make a work of art. And now the end is here, there is only you to give it to. My old enemy.' (p. 263) There is, ultimately, only the author to take credit for his channelled creations. The metafictional nature of the schizophrenic handover - the book being handed over by McCorkle to Chubb is, after all, Carey's - also suggests a parallel between Chubb and Carey, which begs the question, is Carey faking it?

Not only literary fakes but also genuine writers, such as Carey, demonstrate a certain sleight of hand in selling themselves and their literature in the public sphere. Indeed, while Carey is ostensibly who he claims to be - a Bacchus Marsh born writer who lives in New York - he has, like other literary fakes, created a fictional identity that operates as bait for book consumers and that serves to legitimize his fiction. Graeme Turner, in 'Nationalising the Author: 
The Celebrity of Peter Carey', has documented how 'Carey has himself deliberately intervened in the construction of his personal fame' to position himself as a 'national author' in such a way that 'his novels are not his only fictions' (1993, p. 134). Suneeta Peres da Costa contentiously suggests that the difference between the identity construction of a 'fake' author like Demidenko from that of a 'real' author like Carey is only 'the extent that it [has been] demystified as such' (2002, p. 77). Carey's ironic and self-reflexive My Life as a Fake suggests that he is aware of the negotiability of the distinctions.

Indeed, in terms of assuaging anxieties about literary fakes, Carey primarily seems to be saying that faking it is an integral part of the literary experience. Carey, in writing the novel from the first person perspective of Sarah WodeDouglass, is faking an identity in the same way that Chubb faked McCorkle's to produce a real book. He is, just as Chubb did with McCorkle, bringing the unliving to life. As Derek Attridge argues in The Singularity of Literature, the writing process fundamentally involves bringing about a 'transition from nonbeing to being.' (2004, p. 19)

Similarly, the essence of the literary experience for the reader is in relating to the fake. The reader, in fact, allows the narrative of herself to be permeated by another narrative; she allows herself to be penetrated by a ghost. The literary fake is ultimately disturbing for readers because it highlights the reality of the literary experience - one's possession by a spectre rather than a real person and what that reveals about the self as a porous and spectral entity. In Carey's novel, this idea of the self as a narratological construct is highlighted through a subplot in which Wode-Douglas' false memories of her mother's suicide, details upon which she had based her hatred of the poet Slater (misconstrued as her mother's lover), are exposed as fictions. The transformative powers of literature are also ironically acknowledged in Weiss' prosecution for publishing matter with the ability '"to deprave and corrupt...minds"' (p. 54).

Carey's choice of a ghost story to illustrate the power of narrative is hardly surprising. This power of a narrative to possess its reader becomes particularly apparent in ghost stories, not only through the metonymic figure of the spectre but in the exaggerated experience of feeling haunted that results from participation in ghost stories. The Shining, which I referred to earlier, is another example of a metafictional ghost story. In the film, Jack Torrence's (Jack Nicholson's) experience of possession in the hotel is mirrored by our own in the cinema. Likewise, Danny's gift of 'the shining', as an ability to see things that aren't there, is also passed on to us. As we leave the cinema, the world looks uncannily different.

A number of critics, perhaps in response to cultural materialism, have begun to defend and explore the nature of the aesthetic experience, and they have similarly figured it in terms of the trope of haunting. Mark William Roche, for example, in Why Literature Matters in the Twenty-First Century, describes the experience of literature as 'divine possession.' (2004, pp. 81-2) Frank B. Farrell, in Why Does Literature Matter?, argues that reading literature is in part a 'ritual' involving contact with some 'distant music, a more archaic pattern of psychological investments.' (2004, p. 14). Attridge suggests the reader experiences the book as 'a miracle...in language' $(2004$, p. 99), and he offers a similar ritualistic or performative analysis of the reading experience. In reading a book, Attridge writes, 'I am taken through its performance of language's potency: indeed, I, or the "I" that is engaged with the work, could be said to be performed by it. This performed I is an I in process, undergoing the changes wrought by, and in, the encounter with alterity.' (2004, p. 98) 
In fact, Attridge goes even further, describing both the writing and reading experiences as 'a handling of language whereby something we might call "otherness", or "alterity", or "the other", is made, or allowed, to impact upon the existing configurations of an individual's mental world.' (p. 19) The 'other', for the author, is 'that which beckons or commands from the fringes of my mental sphere as I engage in a creative act.' (p. 32) The 'other', Attridge suggests, is what one strives for as one writes (what I'm reaching towards now): something bordering on truth. For the reader, the 'other' necessitates a responsibility, 'a form of hospitality and generosity. Furthermore, in responsibility...my emotional and sometimes my physical self are also at stake' (p. 126)

This link between the 'emotional' and the 'physical' is central to Carey's novel. In My Life as a Fake, the fictional figure of McCorkle and his poems, conjured beyond purely rational ways of thinking, are real, and their effects, operating on its readers in barely tangible ways, are nevertheless real. In fact, literature is presented in all of its paradoxical complexity as something that is, like human identity itself, both ethereal (something other) and physical (a material object). McCorkle, in passing his book to Chubb, tells him it is 'the human soul' (p. 264). However, it is also an object covered in skin.

James S. Hans argues in Contextual Authority and Aesthetic Truth that in the course of literary studies 'we lost sight of the fact that the original site of the sacred was indeed the aesthetic.' (1992, p. 44) Carey, through the spectral figure of McCorkle, seems to want to bring the aesthetic, as a source of the sacred, back into focus. However, through the crass materiality of the poet, he also acknowledges that the profane is intrinsic to sacred experience. The body, after all, is a prerequisite to any haunting. Roche construes the writing experience in a comparable fashion, arguing that 'the lover of literature is enraptured - enthusiastic for the experience of beauty and its transferability to life.' (2004, p. 81)

Literature, according to the cultural materialist John Frow, has become a 'fetishised object' (2002, p. 151) in contemporary Australian public culture. Carey certainly offers literature up as an object for fetishistic worship. The novel's characters, Mrs Lim and Tina, literally revere McCorkle and his poetry. However, unlike Frow, Carey suggests that a sense of wonder before the sublime powers of literature is neither illegitimate nor inappropriate.

In response to the unhallowed status of literature in the contemporary Australian public sphere, haunted by the spectre of the fake, Carey presents us with a hallowed vision of literature. The message of the novel is clear: the aesthetic experience lives. When Wode-Douglass reads McCorkle's poems for the first time, she narrates: 'All I knew now, in my moment of greatest confusion and suspicion, was that my heart was beating very fast indeed. Rereading the fragment, I felt that excitement in my blood which is the only thing an editor should ever trust.' (p. 25)

\section{Notes}

1) See, for example, Peter Craven's essay in this issue of TEXT, which argues in favour of the validity of the aesthetic experience. Academics, Craven suggests, remain out of touch with the mainstream experience of literature. Return to text

2) See Maria Takolander and David McCooey, 'Fakes, literary identity and public culture' (2004). Return to text 
3) Jason Steger, at the 2004 Australian Literature and Public Culture seminar, spoke about the shrinking literary pages of even The Age, a newspaper supportive of literary pursuits, having sponsored the Melbourne Writers' Festival for many years now. Return to text

4) The Demidenko scandal, for instance, inspired numerous articles and fulllength studies. The Ern Malley hoax has also been similarly prolifically dealt with. The special issue of Australian Literary Studies (2004) in the light of the Norma Khouri hoax suggests literary fakes continue to have particular relevance for Australians. Return to text

\section{References}

Atherton, Cassandra 2002, "'Fuck All Editors": The Ern Malley Affair and Gwen Harwood's Bulletin Scandal', Journal of Australian Studies, no. 72, pp. 151-62. Return to text

Attridge, Derek 2004, The Singularity of Literature, Routledge, London. Return to text

Beaumont Bissell, Elizabeth (ed) 2002, The Question of Literature: The Place of the Literary in Contemporary Theory, Manchester University Press, Manchester. Return to text

Boyle, David 2003, Authenticity: Brands, Fakes, Spin and the Lust for Real Life, Flamingo (HarperCollins), London. Return to text

Carey, Peter 2003, My Life as a Fake, Random House, Milson's Point. Return to text

Carter, David 2001-2002, 'Public Intellectuals, Book Culture and Civil Society', Australian Humanities Review, no. 24, viewed 5 May 2004,

$<$ http:www.lib.latrobe.edu.au/AHR/archives/Issue-December-2001/home.html $>$ Return to text

Dawson, Carrie 2005, "'The Slaughterman of Wagga Wagga": Imposture, National Identity and the Tichborne Affair', in Who's Who? Hoaxes, Imposture and Identity Crises in Australian Literature (Special Issue of Australian Literary Studies), eds M. Nolan \& C. Dawson, University of Queensland Press, St Lucia. Return to text

Farrell, Frank B. 2004, Why Does Literature Matter?, Cornell University Press, Ithaca. Return to text

Frow, John 2002, 'Literature as Regime: (Meditations on an Emergence), in The Question of Literature: The Place of the Literary in Contemporary Theory, ed. E. Beaumont Bissell, Manchester University Press, Manchester, pp. 142-55. Return to text

Goodall, Peter 1995, High Culture, Popular Culture: The Long Debate, Allen and Unwin, St Leonards (NSW). Return to text

Hans, James 1992, Contextual Authority and Aesthetic Truth, State University of New York Press, Albany. Return to text

Lever, Susan 1993, 'The Cult of the Author', Australian Literary Studies, vol. 16, no. 2, pp. 229233. Return to text

Lloyd, Brian 2001, 'Ern Malley and His Rivals', Australian Literary Studies, vol. 20, no. 1, pp. 20-32. Return to text

McPhee, Hilary 2001, 'The Word Factory', The Age, Saturday Extra, 28 April, pp. 1, 4. Return to text

Mead, Philip 1995, 'Cultural Pathology: What Ern Malley Means', Australian Literary Studies, vol. 17 , no. 1 , pp. 83-8. Return to text

Musgrave, David \& Kirkpatrick, Peter 2000, 'Friction as a Social Process: Reading Ern Malley', Southerly, vol. 60, no. 1, pp. 131-45. Return to text 
Nolan, Maggie 2004, 'In His Own Sweet Time: Carmen's Coming Out', in Who's Who? Mapping Hoaxes and Imposture in Australian Literary History (Special issue of Australian Literary Studies), eds. M. Nolan \& C. Dawson, University of Queensland Press, St Lucia, pp. 134-148. Return to text

Nolan, Maggie \& Dawson, Carrie (eds) 2004, Who's Who? Mapping Hoaxes and Imposture in Australian Literary History (Special Issue of Australian Literary Studies), University of Queensland Press, St Lucia. Return to text

Peres da Costa, Suneeta 2002, 'Tautological Modernity: Democracy, Magic and Racism in the Demidenko-Darville Affair', Cultural Studies Review, vol. 8, no.1, pp. 72-92. Return to text

Roche, Mark William 2004, Why Literature Matters in the Twenty-First Century, Yale University Press, New Haven. Return to text

Takolander, Maria \& McCooey, David 2004, 'Fakes, Literary Identity and Public Culture', $J A S A L$ no. 3, pp. 57-65. Return to text

Turner, Graeme 1993, 'Nationalising the Author: The Celebrity of Peter Carey', Australian Literary Studies, vol. 16, no. 2, pp. 131-9. Return to text

Maria Takolander is Associate Lecturer in Literary Studies at Deakin University. Her PhD was on magical realism, and previous essays on literary fakes have been published in JASAL and English Studies in Canada. She is also a poet and fiction writer. Her poetry chapbook Narcissism was recently published by Whitmore Press.

\author{
TEXT Special Issue \\ No 4 October 2005 \\ http://www.griffith.edu.au/school/art/text/ \\ Editors: Wenche Ommundsen and Maria Takolander \\ General Editors: Nigel Krauth \& Jen Webb \\ Text@griffith.edu.au
}

